\title{
第四紀地質学的对象和中國第四紀 地質工作的方向
}

杜 唒儉

（北京地質学院）

由於國上經济的發展，促使了各門科学的發展，第汹紀地翼学:边不能例外。在發展

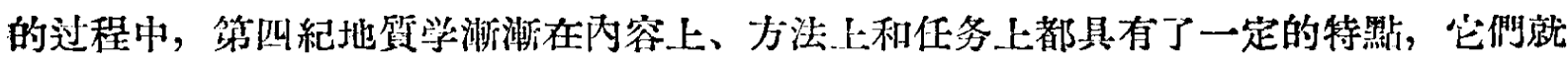

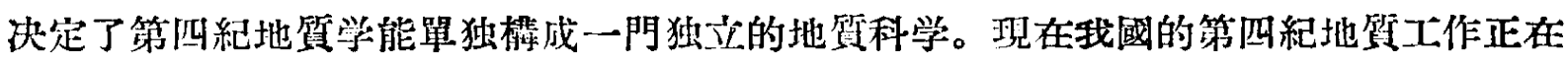
開始時期，各方面作第四紀地翼工作的同志都急需对第四紀地質学有一个比较全面的了 解，作为工作的理論根据。本文正是为了这个目的，來概括地談一下第四紀地翼学的研究 对像和任务，苏联第四紀地蜇学售方面的成就以及中國第四紀地罂工作的現狀和方向。

\section{第四紀地質学的砤究对象}

第四紀是地球發展歷史的最近階段，在过去多作为新生代地質的一部分來研究。最

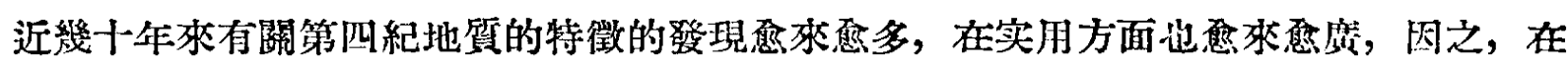
苏联十月革命以後就将第四紀地罂学作为一門重要的和完整的独立科学提出來。

使我僴有可能追溯第四紀時期的發展歷史的重要資料是存在於地没中的第四紀堆程

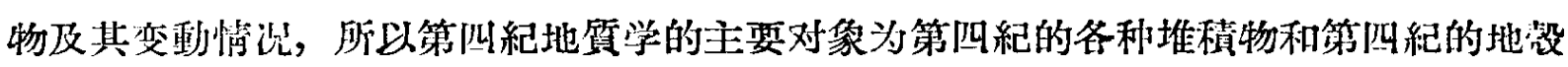
运動及其㑇造形态。

第四紀堆䅡物与更古老的地質時期的堆積物是不同的，它具有下面的各科特點。

第一、第四紀堆積物是一种比較鬆散的堆皘物，大坐沒有經过硬結成岩的作川。这 些堆皘物大部分是碎得堆積物，它們有粗粒的、中粒的、細粒的和微粒的，而且形狀上 有圆的、也有带角稜的。根据顆粒大小及形狀，在沉積岩石学中給它們不周的名称。

在实用上，常見到仯土、粘砂士、亞砂士、㙫士（壚坡）、粘士等等的名称，它們每 一利所含小於 0.01 毫米的顆粒大小的百分數各有不同。

第四紀堆積物除机械的碎原物買外, 还有化学的和生物的堆積物, 如土垻、泉的沉 積、湖的監類沉積、泥炭、府泥等等都屬於这一類。

如果我們以为第四紀堆積物完全是鬆散的, 那是不正確的, 因为还有膠結程度不强 的膠結起來的物質, 还有火山岩及其他坚固的塊狀岩石, 还有与熔岩流接觸的变質物啠 等等，当然这都是比較少量的。

第二、第四紀堆積物在大陸上的陸相为主（現在海洋中的堆積物除外）, 海相堆皘是 此较少的。就現在所知, 海相堆積只有澒哀海低地、巴俞支海边和北季維納河、奥湜伽 
河、也洞河三大河流下游河谷等三个地區，而陸相堆皘幾乎遍佈各地，僅現在上年的銫 利以和很陡的秝崖上沒有它們的遗跡。这些堆積物的厚度一般是不大的, 远不及古老 岩層那样的厚度。現在知道的較大的厚度为: 在苏联列寧格勒省有的地方原約 140 公尺, 北高加索有的地方厚約 346 公尺，阿尔卑斯區某盈地中厚約 400 公尺; 在我國天津附近

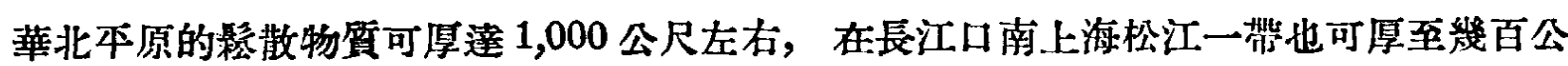

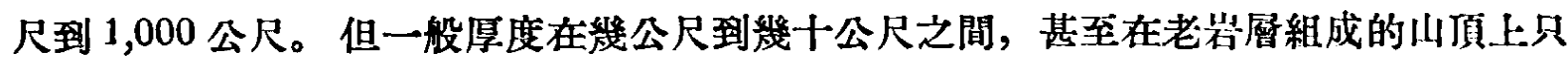
有零尾不連縝的第四紀堆積物分栃着。

第三、第四紀堆皘物是各种地質作用的迹物，因之，根据成因，将第四紀堆皘物分

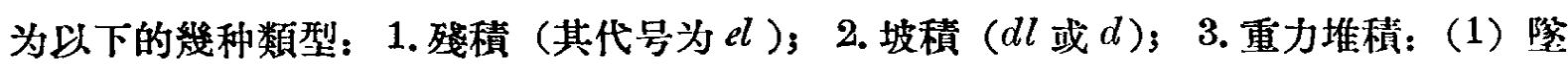
皘 ( $c$ 或 $c o l) ，(2)$ 地滑堆積 (del)，(3) 土溜堆積 ( $(s l f) ; 4$. 洪皘 ( $p l$ 或 $p r l) ; 5$. 浙 皘 $(a l)$, 即过去所謂 “冲皘”; 6. 湖沼堆皘 $(l)$, 如單为沼澤堆皘, 其代号为 $l$; 7. 海 洋堆積 $(m)$ ；8. 冰川堆積 $(g l) ; 9$. 冰水堆皘 $(f g l) ； 10$. 風成堆皘 $(e$ 或 $e o l) ; 11$. 化 学堆皘 $(c h) ; 12$. 生物堆皘 (其代号暫用 $O) ; 13$. 火山堆皘 $(\beta) ; 14$. 泥火倠皘 $(b)$ 。 如果第四紀堆皘物的成因類型定不出來, 就劃为單独的一類, 用 “ $p r$ ”代号代表。

在自然界中，第四紀堆積物的成因類型，絕不是分作的那麼清楚，其中必然有一些过 渡性的綜合堆積物，它們是: 1. 倩皘・坡皘（其代号为 $e l d$ 或 $l+d$ ) 一如山坡上部的 堆皘; 2. 泛積 - 湖泊堆積一一如三角洲堆程; 3. 淤皘・海洋堆皘一一如三角洲堆皘; 4. 冰水堆皘 - 湖泊堆積一一如皎泥沉皘; 5. 冰川堆皘 - 海洋堆積一一如冰川堆䅡。

在苏联，近年來对於第四紀堆皘物研究得很詳細，同時很系統。在 C. A. 雅叮术列 夫等著的“第四紀堆積物的研究及地質測量方法指南” (1954) 一書中的“第四紀堆皘物的 成因分類表”（原書 46-47 頁) 中将第四紀堆積物分为七大“組”、二十“型”和五十二“相 及堆皘物”, 值得我們学習和应用。

这些堆積物的時代劃分，或第四紀地曆的劃分，一般探用四分法，其分法如下：

\begin{tabular}{|c|c|c|c|c|c|c|c|c|c|}
\hline & 時 & 1 & 代 & 量 & 岩 & 㕌 & 劃 & 分 & \\
\hline 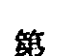 & \multirow{2}{*}{\multicolumn{2}{|c|}{$\begin{array}{l}\text { 近代 } \\
\text { 新第四紀 }\end{array}$}} & \multicolumn{2}{|c|}{ QIV } & \multicolumn{3}{|c|}{ 近代（近統） } & & 筍 \\
\hline 200 & & & \multirow{2}{*}{\multicolumn{2}{|c|}{$Q_{\mathrm{III}}$}} & \multirow{2}{*}{\multicolumn{4}{|c|}{$\begin{array}{l}\text { 新第四采（新統） } \\
\text { 中第四染（中統） }\end{array}$}} & . \\
\hline 24 & \multicolumn{2}{|l|}{ 中第四知 } & & & & & & & 2 \\
\hline 的 & \multicolumn{2}{|l|}{ 老第四紀 } & \multicolumn{2}{|c|}{$Q_{1}$} & \multicolumn{4}{|c|}{ 老第四系（老統） } & 夈 \\
\hline
\end{tabular}

另外如第四紀 (第四系) 不能詳細劃分時, 就用“Q $Q$ ” 表示; 有時第三紀与第四紀中 間有一过渡時期，就用 $N+Q_{\mathrm{I}}$ 表示。

第四、第四紀堆皘物中含有很多的動物化石和植物化石，在動物化石中以哺乳動物 及軟体動物为主，在植物化石中以孢子花粉为主。第四紀哺乳動物化石中有大型的，也 有小型的，其中及以人類化石及其交化遗跡为最重要，这是第四紀地質的一个特徽。但 動物化石中的陸生或海生的軟体動物，其重要性並不次於哺乳動物，它对鑑定堆程物的 成因上和分作上及对確定第四紀地質史的發展上，都有着極大的意义。植物孢子和花粉 的研労, 是現代科学發展的一个新方向, 它們对第四紀气候的变化提供了有力的証据。

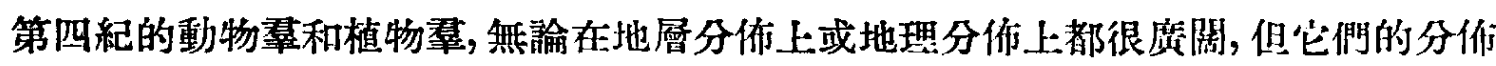
是受着气候条件的影响的, 所以它們或者是適应当地环境, 改变了自己的体質結構, 或 
来泃其他地區要移，保留了原來的性質特點，这就增加了第四紀生物歷史的複雄性; 最

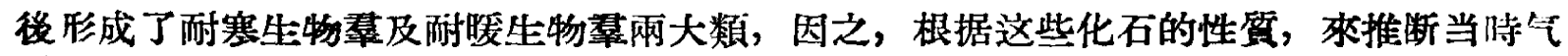
候的变化是有特殊意义的。

第四紀气候变化的另一結果，是迹生了世界上的冰期和間冰期。第四紀時最大冰期 的冰川每覆益了大陸上四分之一的地區。这和冰川的類型多數是大陸性的冰䀠，只有少

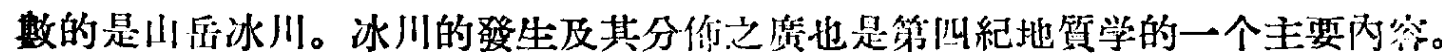

第五、在大多數的情况下，第四紀堆積物与其表現的地形形态（地貌）的關係十分 密切, 堆積地形是第四紀堆積物的外部形态。所有地曆的冲刷都是先从其表醽開始, 然 後才破坏了地層本身。所以第四紀以前的古老時代的堆皘, 紕平僅知其地質的組成, 而 与其同時形成的表面形态就幾乎沒有被保留下來。但是第四紀堆積物就有所不闰。第四 紀時代的短促为保留第四紀堆皘的良好条件，所以这些堆積物所形成的地形形态也被保 留下來。另一方面，她正因为時間的短促，第四紀所形成的剝蝕地形沒有被覆盖，让大 部保留下某，因之，这与地貌学提供了丰䈏多变的內容。

第四紀地質学的主要內容除了第四紀堆積物之外，还有第四紀時的地亮运動及共棈 造形态。現在主要根据苏联学者 H.И. 尼可拉耶夫的諭还叙述在下面。

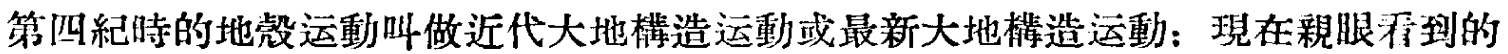

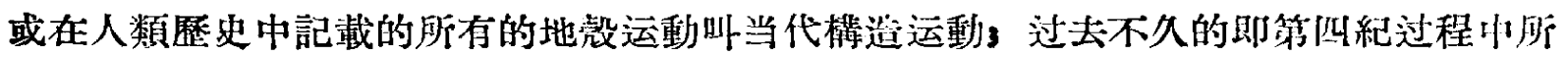
有的地殷运動叫最新構造运動，芠就是近代大地構造运動的兩个主要內容。

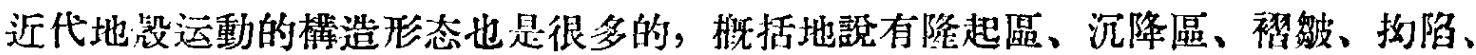

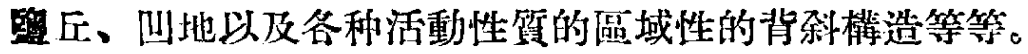

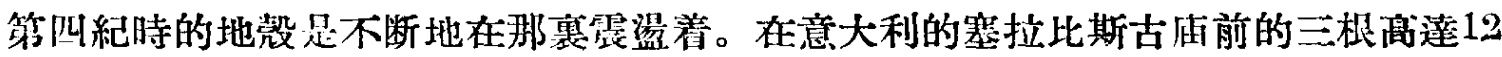
公尺的大理石柱子上就記載着这个地方在公元以後地豰上下昇降的情况。

芬蘭・斯堪的郘維亞的昇降作用也是一个典型的例子。这个地區的上是現像是根据 海濱階地、海水冲刷的遺跡、海洋堆皘物的禹度以及歷史的資料來確定的。这个地區的 海濱階地已經找到 5 个，最高的一个階地即表示着更古老海岸的存在，它已縃比现在海

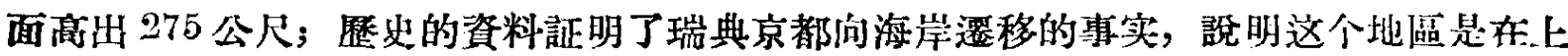
景，其速度为每一百年 0.24 公尺。

当地殼有些地方在上昇的時侯，另外一些地方也在下降。今天我們所知道的最顯著 的下降的例子就是非洲西海岸的剛果河口。現在的剛果河口外海底上还促留了菏槽的形 态，澡到 2,000 公尺，河槽口距現在河口約有 130 公里。

在我國，也有上昇下降的例子。度东湛江市附近的海岸，因为上昇的結果造成了等10 公尺、20 公尺、40 公尺三級海濱階地，这些階地上还保留了現在海洋生物的遺跡。華 北本原是一个下降的例子，因此这个地區的堆積物很厚，有的地方（天津附近）可厚遵 1,000 公尺上下。

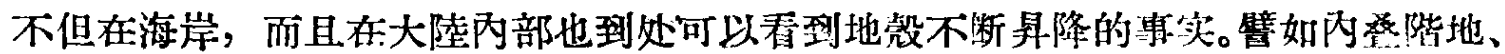

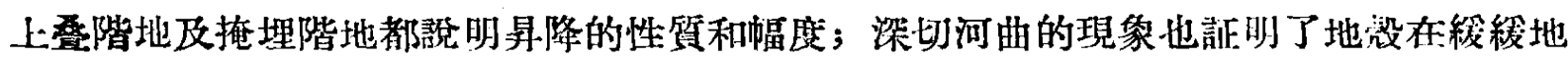

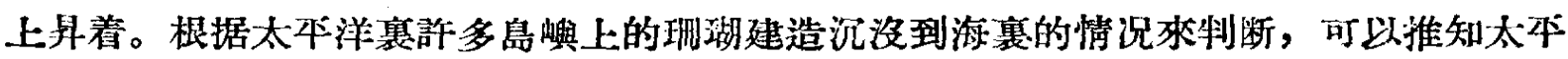
洋底上地有廣閵的下降地區。 
在苏联, 經过許多地質学者的研究, 証明了近代構造运動的强烈性。在年青的裮船

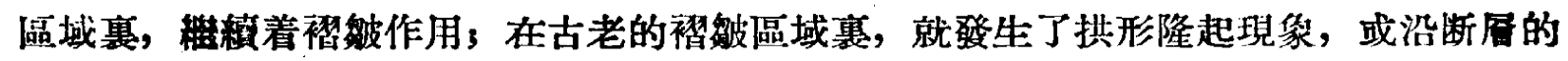
上昇現像。在陸台上, 同样進行着一些地㫢的隆起和另一些地塊的沉降作用。这些作用 和現像不僅用地翼的方法得到就明，而且也用大地測量的方法肯定下來了。

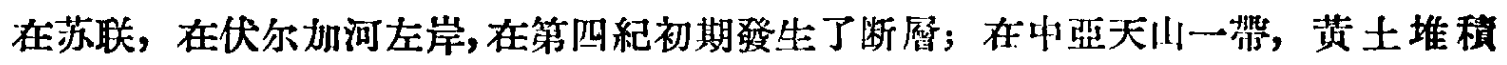

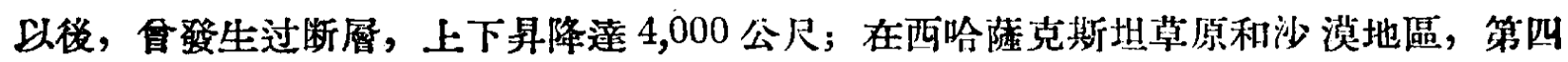
紀時管隆起了無數的監丘。这都是第四紀時地㲁强烈运動的絬果。特別足地震，表示着 论没运動沒有静止，却在那軎頻繁地震動者。

研究第四紀地癹运動及其構造形态的科学叫做近代大地構造学，这是苏联老地嘪学 家 B. A. 奥勃鲁契夫院士訂名的。在苏联, 这和研究已形成为一門特殊的地質科学。

从以上的叙述中，我們可以認識到第四紀地質学的主要內容为第四紀堆皘物及第四 紀地凯运動。它們各具有一系列的極特殊的性質和特點，这就使我們櫵得为什麼第四紀 地翼学必須从整个的地質科学中分出來而成为一阴独立的科学了。

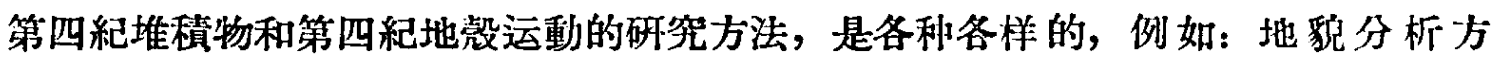
法、古生物地啳学方法、微古生物学方法、歷史考古学方法、古土壤学方法、比較岩不 学方法及大地測量学方法等等。沒有这些方法的相互比較、相互綜合，对第四紀資料的 研究是不可能的，当然也就不能完成第四紀地質学的任务。

\section{第四紀地犋学的任务}

第四紀地質学所要研究的問題是由其独特的內容所决定的。放在第四紀地賀科学面 前的最主要的問題是第四紀堆皘物的成因類型及其特點的研究; 足第四紀時期的地㪍运 動的性翼及其構造形态的研究3 是这兩方面对地球表面形态發生、發展、分類、分陆的

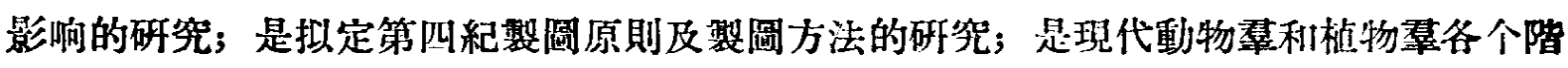
段的起源問題与人類的發展及其文化遺跡的研究。所有这些問題都是地筫科学研究的重 要問題, 然而僅靠第四紀地罂学是不可能完全解决的, 还必須依靠与第四紀地質学有 密切關係的其他科学——沉皘岩石学、土堆学、大地粠造学、地貌学、地理学、古生物 学、動物学、植物学、人類学及考古学等等—的知識來加以綜合研究，而第四紀地贸 学是在綜合研究第四紀地質發展歷史中的首要科学:。

根据苏联学者E. B. 單濢的論遮, 第四紀地質学有下列幾方面的任务:

如将第四紀地質学作为地球歷史的一部分隶研究, 它的任务是: (1) 確定第四系統 一的地曆和第四紀的地哲年表; (2)恢復第四紀各个時期的古地理和一侯演变的概况。

如果以人類的發展及現代生物的起源为主要內容的話, 第四紀地質学一般要研究下 面兩个問題: (1) 人類發展階段和人類文化初期(舊石器時代)發展条件問題; (2) 現 代動物（尤其是哺究動物）和陸生植物（特別是狍子花粉）的發生發展問題。

第四紀地質学在冰川研究方面的任务是:（1）第四紀冰川發生的歷史和条作問趣; (2) 冰期的成因䦥題。这兩个問題的研究必須在与天文学、自然地理学和地貌学密切 合作的基礎上才能得到更好的解决。

第四紀地算学的內容是具有相当複雜的特點的, 这样, 就决定了第似紀地筫学的特 


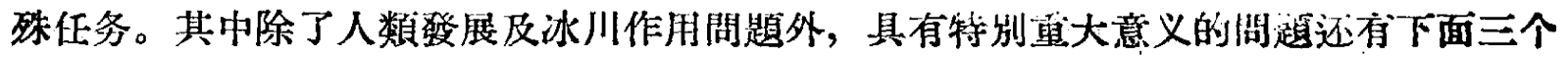
方面: (1)拟定第四紀地層的对比方法和整喟方法，因为第㕨紀地層与所有的古老地居 是完全不同的，因之，第四紀地層的製圖就具有了特殊的色彩; (2)砰究各种成因類型

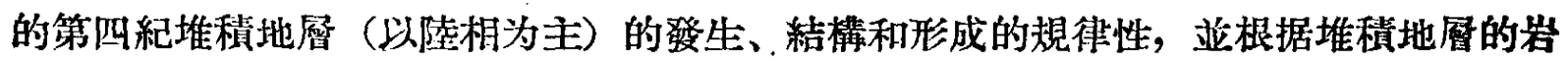
相变化確定其特殊的建造分類; (3)䦐明第四紀地溦运動發展吏以及与其有密切關係的 地球表面形态的演化情况。

实际上，这三个問題是最有價值的, 它們是指望普查找礦与水交地啠和工程地睤工 作的基礎; 但是这些理論性問題, 必須与沉積㸵石学和動力地質学取得密切联系後, 才 有可能得到更好的解决。

以上就是第四紀地質学一般的和特殊的研究任务。但这些問題的解决必須建立在与 其他科学联系的基礎上，这就决定了第四紀地罂学的性質是一阴度泛的綜合性的科学。

第四紀地質学的研究, 不僅要解决許多理論性的問題, 而重要的是它在实踐方面的 意义。例如对磺﨎（不只是砂礦）的率找和勘探、水交地質工程地質的調查、城市建設、 工業建設、農業建設、交通建設等等,均須在第四紀地質的研究和製圖的基礎上去進行, 没有这方面的知䧕, 以上这些工作的結果是不可想像的; 特別是近代大地檴造运動的研 究, 对於淮行偉大的水利工程建設有着極其重要的意义。当然理論閭題是在解决实际問 題过程的產坒的, 那熱理論問題的研究就必須与解决实际問題相結合, 否則将不会得到 正確的結論。在苏联应用第四紀地質学的理論來解决实际問題的例子是非常多的, 因限 於篇幅不能一一叙退。

\section{中國第四紀地㬏工作的內容和方向}

型想確定我國第回紀地罂工作的內容和方向, 必須先要研究苏联第四紀地質学的發 展和成就之姼, 必須認識清楚了这个正確的道路並取得經驗之後, 才有可能。因之, 先 來談一下苏联第陌紀地筫工作的一般情况。

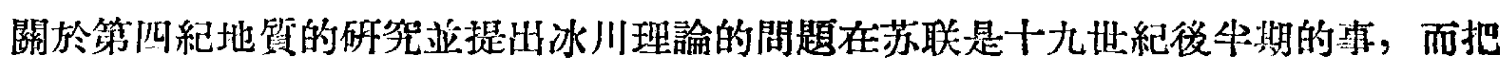
第四紀地罂当作一阴独立的科学僅在十月革命以媵才提出來的。可是这阿科学在苏联由 於社会主义國民經济所引起的一系列实际問題的解决和科学交化普遍的响張而促使着它 迅速發展。因此在 1950 年以前 (主要根据單澤) 就已取得了下列幾方面的重要成就:

第一、拟定了第四紀堆積的製圖方法和組織了第四紀堆積的系統測量工作，第叫紀 堆積的製圆方法是苏联首先提出來的。製圖的原剔是將堆皘物劃分为各种不同的成因類 型前分为谷个不同時代; 圖上要表示出岩性成分並在劃分界挠時考慮到地貌的因素。因 此, 这利先進的原則为世界各國所公認, 作为緰製歐洲第四紀堆皘闾的國际圆例。

苏联第四紀堆皘圖的填製是全國性地質測量工作的主要內容之一。在苏联，自1932 年即由雅可求列夫主編了第一張比例尺为 $1: 2,500,000$ 的苏联歐洲部分第四紀堆皘搬 要圆, 不久以後, 又編製了莫斯科省、加里寧省、烏克蘭和白俄罗斯各种比例尺的第四 紀堆積概要闾。甚至在衛國战爭時期, 在中、南烏拉尔也進行了第四紀地質測量和慗国。

苏联丝洲部分, 如西西伯利亞和哈薩克斯坦的某些地區也編有 $1: 1,000,000$ 和 $1: 1,500,000$ 的概要圖。 
第二、拟出了第四紀地層的一般原則和苏联歐洲部分第四紀堆積的統一地層圆。苏 关的第四紀堆皘地層的研究工作是与上項工作同時淮行的。

苏联關於第四紀地啳研究的著作是很多的，这毫不能一一介紹和說明每个作者在形 成現代地層概念中的作用。但在这方面具有特殊意义的是 $\Gamma$. Ф. 米尔琴克的著作。他 根据自己的調查和已有的材料作出了苏联歐洲部分第四紀堆積一般地曆对比圆。这个㖥 的主要特點不是机械地对比了个別典型剖面，而是夗括了敀种不同成因堆程物的年代的 可靠的論証。由於这个圖的作成，臭定了苏联歐洲部分第仙紀地質学的基礎。

第三、为地屏学建立穞固的古生物学基礎。地曆学的古生物学基硶的研究工作是与 解决許多第四紀動物和植物的問題同時並進的, 这种研究工作保証統一地曆圆的完成。

在苏联，第四紀動物的研究工作是循着兩个相闒联的方向進行篮爑得發展的。第一 方面是第四紀哺乳動物的研突工作獲得了很大的成就。在这方面，B. Y. 格罗莫尖是有很

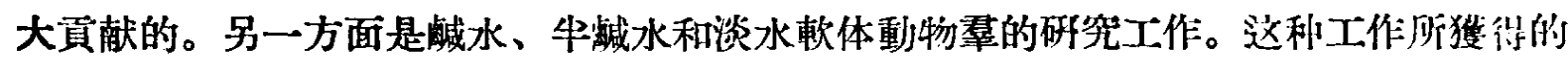
知識在古生物学和地檿学的实际意义上比是很大的。

第四紀植物的研究工作的成就在於抱子、花粉和矽藻分析方法的拍用, 这标誌着一

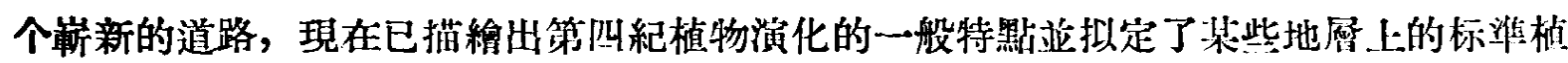
物化石。最近苏联科学院贈造中國科学院一批抱子花粉試驗研究設各, 这就使我們有订 能開展这項研究工作，來解决地愿对比与古地理环境問題。

第㸨、研究舊石器時代中的重大進步。苏联在研究奮石器時代上的成就，一方面發

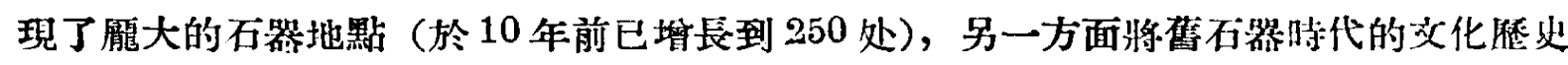
作了總結，同時普遍展開对舊石器時代遺䟢的古生物和地質的研究。在这方面工作校多 的是 B.K. 格罗莫夫，他对舊石器時代的分期及其地質年代的位置作了特殊的工献。

第五、在研究第四紀地設运動方面的卓著成就。在苏联研究这个間邀的著作:是很多

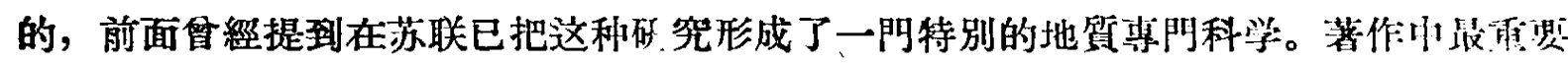
的要算来尔琴克關於苏联歐洲部分的著作，B.A. 華尔丹揚茨等關於高加案方面的落作，

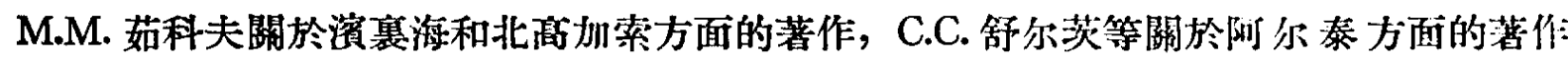
以及 H. H. 尼可拉耶夫關於俄罗斯陸台方面的著作。確定了地設运動是决定於一般構造 原因以後，使很多苏联地質学家值接否認了以与水川載荷有關的均衡㭪償來作为第少紀 造陸运動的直接原因。1949 年, 尼可拉耶夫对苏联第四紀地没运動加以詳細綜合䂰符後, 合㝓出“苏联最新大地構造学”一書, 書中除論述苏联境內最新大地構造外, 还分別介紹 了各和研究方法，这对我們來諮是進行研究这方面的一本極好的科学論著。

看到上面所述的苏联第四紀地罂学的發展及管方面的成就之姼, 就顯得我們对川國 第四紀地質的知識知道的是很少的; 其中除了对我國洞穴堆皘及水川和水水堆和砰究得 比较詳細外，而对其他類型的第四紀堆皘地層的知識，多是需尾的和片断的。

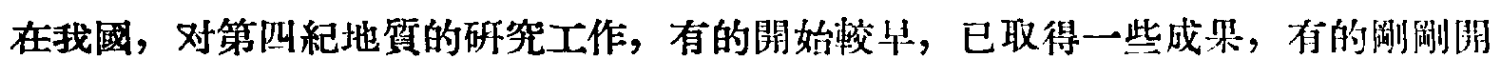

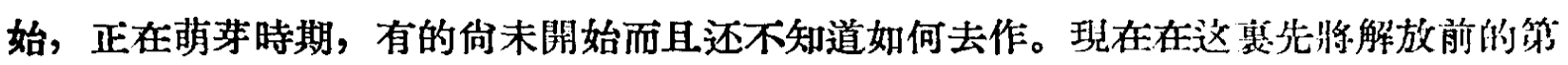

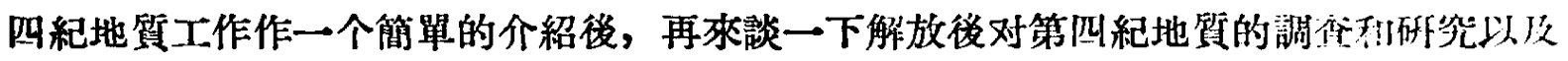
所得到的一些結果。

在解放前, 虽然沒有單独地作第四紀工作, 然而我國的地質工作者, 比其是前新生代 
研究空的工作同志罚和其他地質工作者同時作过一些調查和描述，並得到了一定的重要

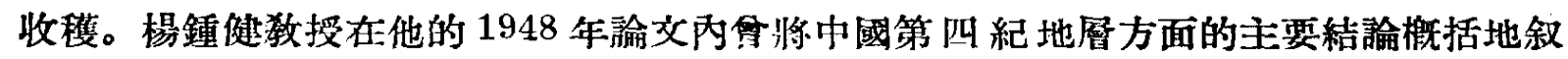
述在一个表內, 这是一个很有價值的總結。这个表具有幾方面的特點, 但另一方面也有 一些缺陷，光其是将茨士分为“原生”和“次生”，郡是不合適的。

我國第几紀冰川和冰水堆皘的分作是相当度泛的，關於对它們的研究結果已分別記 载在李四光敉授及其他同志的淪文內，在我們沒有更成熟的意見前，暫不提出討論; 但 这些堆程物的分扸和時代、冰期發生的原因和第四紀气候的演变应再作進一步的探討。

人類化石和人類文化遗跡的研究在我國已獲得了極其輝煌的成就。这种工作在解放 後得到了更大的發展, 並又找到了一些澵的地點, 特別是丁村人的發現更值得重視。同 样情况，第四紀哺乳動物的研究成果地是很大的，美不多第四紀各个時期的标準化石都 已肯定下來。關於这些工作的研究結果已由中國科学院古准椎動物研究宾的各位同志在 1954 年 12 月 27 日中國科学院举办的 “中國猿人第一个头盖骨發現二十五週年紀念会” 上作了總結性的發言。但假如这种工作能与第四紀地質測量和堆皘物的研究更密切地联 系起來，那將会取得更大的收穫。

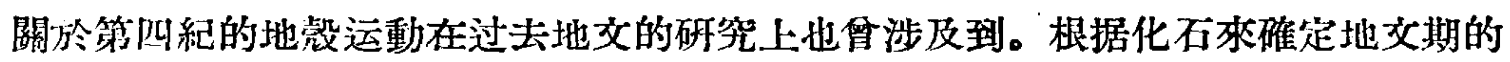
時代是有特殊意义的, 然而大區域的对比, 不敨虑某些地區的具体变動情况, 那还是不 無缺點的。

解放以姼，对於第四紀地質的研究就与从前大不相同了。这个時期的第四紀工作的 特點是配合祖國經济建設（如水利建設、工程建設、農業建設和尋找地下水等等）及非

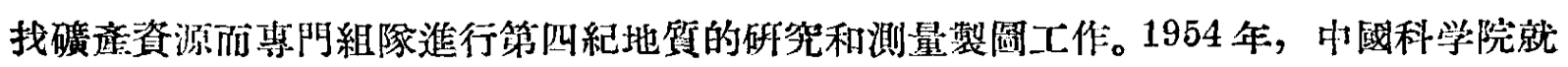

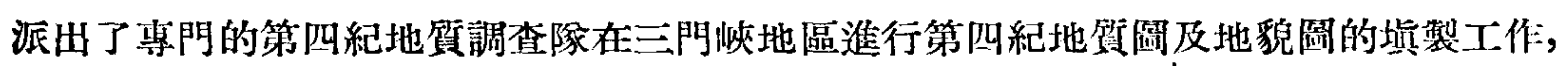
詳細研究了这个區域的第四紀堆皘物的類型、分佈、性翼和發展, 研究了这个區域的地

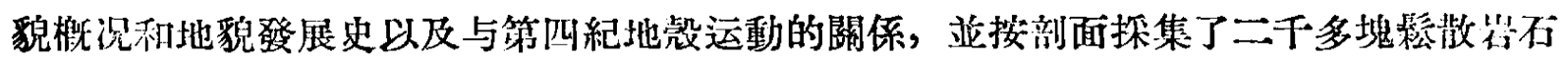
标本和三千多包孢子花粉分析标本，以及很多地點的動物和植物化石。这是我國第一次

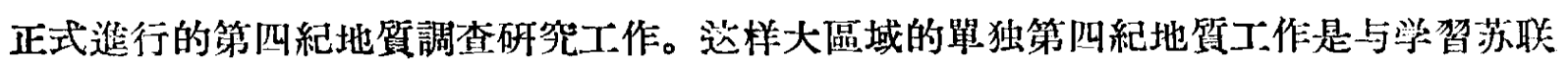
先進科学理論和先進科学方法分不開的, 工作所以能進行篮取得初步成果更与北京地啠 学院苏联㷫家 B. Y. 帕夫林諾夫教授的覣自指導有密切的關係。

北京地罂学院为了配合䔃國大規模建設並在 B. И. 帕夫林諾夫教授的指導下，在培 养着第四紀地貿及地貌的研究生; 每年畢業生的畢業設計地派往砂磺地區及水利建設地 區工作。呼究生和畢業生在新的理論和新的方法指尊下已收集了不少的新的第四紀地㭡 和地貌資料，这些資料無疑地給編彆中國第四紀地質圆和地貌圖打下了很好的基碟。現 在我們就下列惑个問題立結合苏联先進經驗來分別談一下中國第四紀地質的情况。

關於㷼土: 中國的黃土美不多在 90 年前左右，就被人作为科学研究的对像了。最 初研焭它的是外國人，以後，中國人也注意了黃土的調查和研究，其中覌繁最部細、描

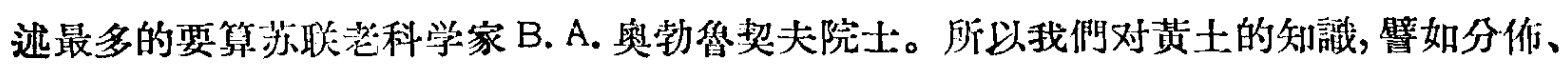

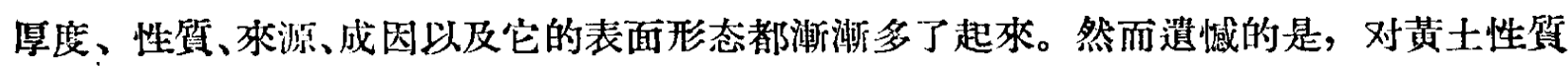
的詳細調查和研究是很少的, 許多工作人負却用了很大的精力和很多的時間來呼討黄士 的成因問題。这蓑不是說黄土的成因不要砰究，相反地，根据不同成因來分類分區加以
1 月号
科学邀哴
- 47 . 
利用，这正是我們今後工作的方向; 而問題在於每个人都从不同角度來証明所謂 “原生 黄土”（这个名詞不合適）是風成的这个結論上。風成證的理論根据是什麽呢? 總括起來 䄪有七、八項理由，因为一般人都知道，在这裏不拟一一提出來。

僅是根据过去所說的一些結論來誰旳中國西北和華北各省的革土都是風成的, 那是 不合適的, 因为僅就三阴區的初步調查和呼究的結果, 認为这毫的㷼土有淤積的、有洪 皘的，而沒有看到風成的遺跡。最近北京地質学院苏联專家 B. H. 帕夫林諾夫呚授冒到 我國內蒙古社西北各地对黃土作了較詳細的覌察和研究，得出了一些新的結論。

概括的“風成黃土”的結諭之所以得出, 是因为我們缺乏詳細的調查和研究的結果, 今後应該大規模地展開調查，应先从性留出發來研究这个問題。当然要想確定黃土的成 因類型，脫离了它的表現形态(地貌)，也是不可能正確的。現在再歌一下苏联对兴土研 究的成就，作为我們今後工作的絫改。

苏联在中亞烏茲別克和塔吉克一帶对黄土的研究很詳細。苏联学者从事实壮發一 黄土內有顯著的層理, 並有古土壤夾在其中; 黃土造成特殊的地形形态（階地及计䅡錐 等); 䙺察天山一帶洪水帶來的物質可以堆皘成厚的新黄土層, 而風力堆程却不是这样 的, 这一帶黄土除山頂小部分是風成的以外, 大部分为洪皘的，其他份有淤程的、坡積 的及混合而成的; 就是風成的一類也分为三种類型, 不是那样簢單。

这种研究不僅对黄士的成因票定了基硅, 而且对黄土的成分、厚度、分曆也有精細 的研究，这給工程建設和改良土壤提供了有力的理論根据。

我國的忶北与苏联的中亞相鄰, 荕联学者在这个地區研究的方向和成果, 正是我們 今後对黃士研究所要走的道路。

關於洪積物：这方面的材料是很少的，但不能否認僅太行山以东、藮北本原西边分 佈着好幾个冲積錐，它們的構成物質是标準的洪積物，而時代也不一致。譬如腩口以南、 永定河下游（三家店以下）、長辛店以西以及保定以南的太行川边，都分倠着度大留域的 洪皘物，根据它們的相互關係，可以知道它們有比較新的，也有比较老的。

我們的首都一一北京就位於永定河冲積錐之上，我們在精細的大比例尺的地形阅上

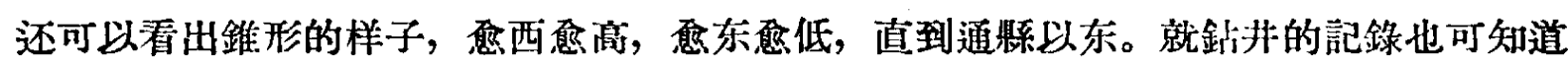
西边粗, 而往东濑細，这正表示了洪積物的岩相变化。確定了这科萑相变化挠，就可給 噚找地下水提供了理論的根据。

保定以南太行山边的冲皘錐，是比较大的，冲積錐边緣因为粗細物質分栰不分了，就

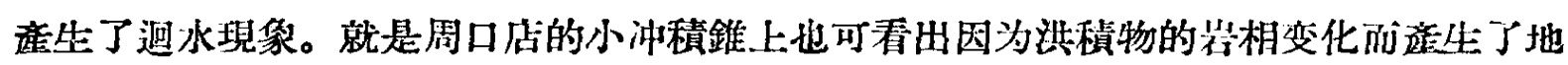
下水的高低分佈不同。这就證明了洪皘物与地下水的關係是如何的密切了。

当然这些冲積錐生成後，又被第四紀後等的河流作用破坏了一部分，因之洪積物之 上及边線又堆積了一些淤積物，以㷋，这些淤積物加厚加筧，问太平洋方向推進，因而

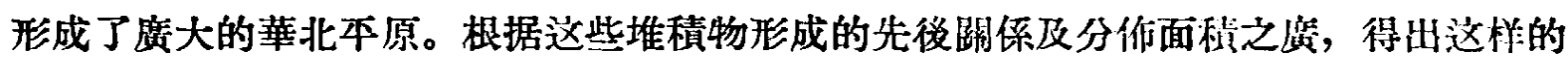
結論, 想是無可否認的。

在我國东部，除了太行山之东外，在中条山之南世發見了很大的冲皘錐，而而具不止 一个，其中比较大的要算东中条山之南的一个，它南北歪三、四十里，东西筧在 100 橗 以上。組成它的洪積物不整合於各种老岩層之上。这个區域洪程物的特點是: 下部为巨 
大的础岩層，厚約 20 餘公尺，其上为标準的堆土，中間夾着砂石曆（多在下部）和次 生的釬質結核，厚約七、八十公尺。它的边緣被黄河冲刷破坏後，常造成幾十公尺的照 崖，十分壯覌。黃河以南的冲皘錐也同样受到破坏，並且河谷兩岸与冲程錐繁崖之間鑲 脄着高低不等的黄河测積階地，又是这个區域的地貌特徵。

中条山南冲積錐云所以形成，是与第四紀初期中条山上升有着密切的關係，因此我 們可以推想，中國西部大的山脉兩旁都可能分栃着度大的洪積物，如天山南㭸的西域磂

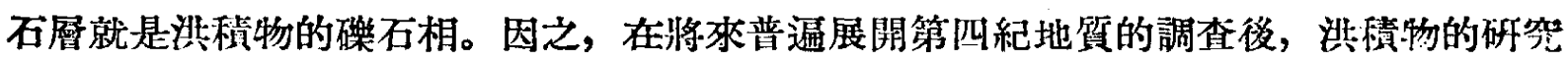
將成为中國第四紀地質的一个主要內容。

關於淤積物：淤積物也有人叫做“冲積物”, 在过去的一些交献上论常看到“冲皘物”、 “冲積愿”或 “近代冲積”这些名称, 但描述的均極簢單。淤積物是由河流堆皘作用造成的， 所以它的分倠也在河流兩岸，譬如黃河流域、長江流域、禀江流域、淮河流域地區以及 东北的黑嫣江、松花江和遼河流域地區，淤積物的分佈都非常度濶，我們若看一下中國 地形圖即可知道, 美不多綠顏色的一大片多为淤積物堆積地區。

在黃河的三附區，淤積物的分作很廣，而且時代也不一致。可分为河槽淤積物及河 谷淤皘物兩种，前者時代新，屬近代，後者時代老，屬新第四紀。河槽淤皘物多为仯子、 淤泥和圆的石塊所組成，可見厚度为一、三公尺至十幾公尺。河谷淤皘物厚約五、六十 公尺, 甚至七、八十公尺, 它由礫石、砂子和粘砂土所組成（自下而上）。磞石厤常很原， 可達四、五尺公至七、八公尺，表示了黄河的冲刷力和搬运力是如何的强大；砂厤中有顯

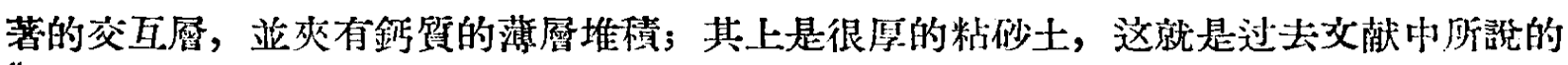

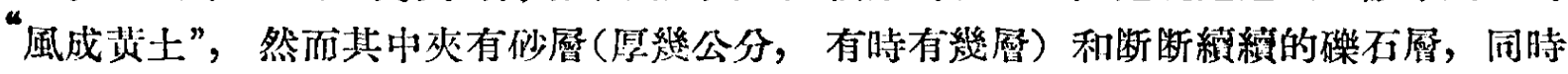

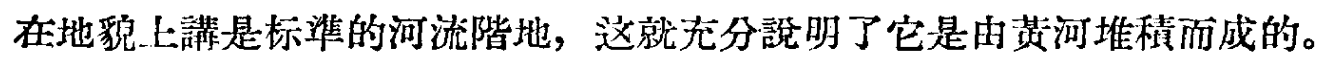

在湖南沅水流域, 淤積物分扸近很席大, 長四、五百公里的沅水主流兩岸总不多全

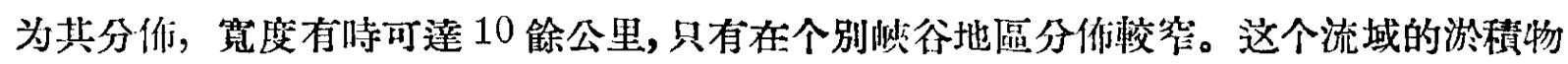
特點是双曆的，立不同時代的矤積物棈成不同度的堆皘階地。盖不多每个階地的淤皘 物, 其下部为磁石層, 上部就为壤土層, 只有近河槽的最低的和最新的階地才多为仯子 和仯土所組成。

在沅水下游靠近洞庭湖边的地區, 沅水三角洲堆積和湖泊堆積佔优势。从湖泊堆積 物的老新及其所造成的湖泊階地來看，在第四紀晚期，洞庭湖的發展情况还很湍楚。

到了長沙湘㵢一帶, 差不多南北流问的湘水堆積物就具另一种特點, 它是以较新的 第一超河漫灘階地堆積物的分佈佔席大面積的。

漢水流域的淤皘物主要是距河面不高的第四紀晚期的第一超河漫灘階地堆積物，有 時厚約 20 餘公尺, 主要为細砂所構成。这种階地堆積物在漢水下游的江河本原就發展成 了階地 - 平原淤積物; 面積磨大, 岩相变化複雜, 为研究第四紀岶相的很好地區。

我們不能忘記，淮河流域和䢒河流域出是第四紀堆積物發育的地區。这陃个區域堆 積的特點就是在度大淤皘物的範園內有很多星星點點的湖泊堆積物, 所以在这兩个區域 研究淤積 - 湖積的交互相及其变化就对第四紀的發展这有了特殊的意义。东北遼矿上游 另有一个特點, 那就是仯丘堆積物的發有, 它存在於宽磨的河谷中, 与淤積物、湖積物 構成了第四紀發展过程中的複雜哭相。
1 月号
科学通報

- 49 • 
同样, 在河套區城, 河流的淤積、湖泊的堆皘和風砂的堆積也往往造成了第四紀岩 相的複雜变化, 也是研究秷散堆皘物岩相变化的良好地區。

除了上面䇉到的分佈很廣的淤皘物、洪皘物和黄土堆皘（有沙積的、淤積的和坡皘 的）外，还有殘皘物和坡積物。残皘物一般分作在山頂上及高的平台上，中國北方各地一 般不厚, 有時成不連嚗堆積; 但在我國南方, 就有分们较度、厚庭地比较大的殘皘物, 那就是虫狀紅土。關於它，在一些文献裏常常提到，可是对它的詳細描述及其成因的推 断却很少看到。坡皘物分佈也是席的，在一些老地層的上面常常存在，但在我國各地一

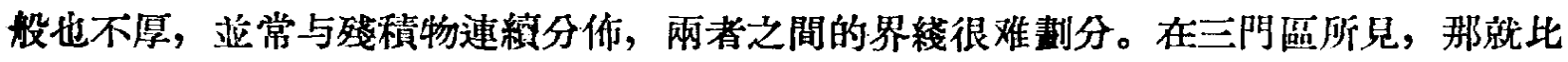
較清楚, 按位置, 它分佈於該區的洪皘物与淤皘物之間, 常厚至 20 公尺以上, 表面成一 个科坡，組成物蜆为含紅色条帶的黄土狀壤土，是其特徽。

關於我國第四紀時的地没运動地到处可以看到，但在河谷區及大山區表現得比较明

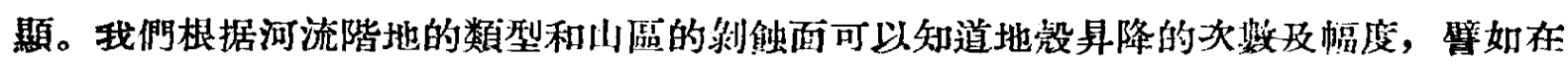
三附區和沅水區就可以看到这样的测子。我們在这方面可以說还未正式作过詳細的詿查 和研究，因之，現在还不能概括地來談。此外，第四紀抱子花粉的研究还作的很少，因 之，在鑑定各地啳時代上和確定第四紀气候的演变上份未起着主導作用。在这兩方面正 是苏联有很大成就的，也正是我們工作最弱的一秠，当然这也正是我們今後鬥的的日标。

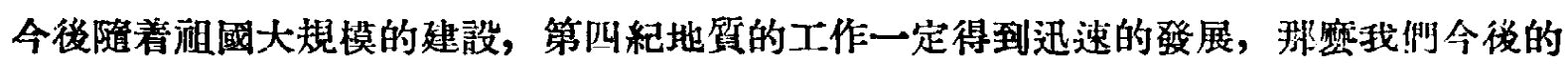
工作方们和內容是什餗呢?

第一、絓䄉野外調查工作: 这个工作应先从中國东部開始，因为在中國东部分价着 發育很好的淤積物、洪積物、一部分坡䅡物、殘程物和湖䅡物, 以及很补新的黄土堆皘; 我們所以这样考慮足因为限於人力、条件, 主侭先配合祖國建設。中國东部的工作，我建 議在一般的地區進行二十万至十万分之一的第四紀地啠和地貌测量, 在一些重默地煰, 如水庫水埧地區、仯磺富集地區和需要地下水供給的都市地區, 進行五万至二万丁五于分

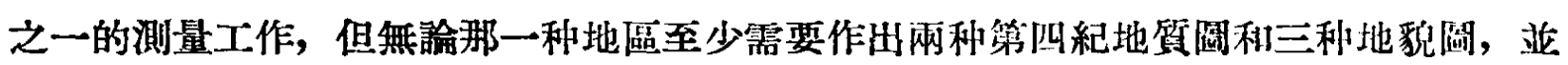
在必要的地段上作横剖面圖和程剖面圆; 此外並要探集動植物化石、鬆散虹石标本和抱 子花粉分析标本, 占便進行室內研究㷋, 解决地層時代、堆皘物的成因類型和第四紀气 候演变等間題。

我們工作的時候应正式組榢, 这个榢中除第四紀地質和地貌工作人員外, 还要他括 地理、土壤、古生物、植物、動物和考古等方面的工作者, 使第㟧紀地質工作成为一个 綜合性的工作。在工作開始之前要充分考慮需要与可能, 那就是重點開始工作, 不能全 面展開工作。在現在祖國建設需要大量第四紀地質資料的急迫情况下, 僅由灲國科学院 組豚進行某个區域的調查, 那离客观需要还足很远很远的, 应当侭量組織各高等地算院 校及地質部和其他各部的地罂工作力量來共同進行这个工作，那就是境中国的第四紀地 質工作不是某一个人或某一个机關的事，而是大家应一起組織起來在總的領導㥎的目标 下在不同地區工作。但是無論那个人或那个机關去作第四紀地質工作, 都应当间新的观 點、新的方法去進行, 因之, 在工作前及在工作洔積極学㚙苏联先進科学理論和先進科 学方法是作好工作的先决条件。

第二、淮行室肉整理工作：这个工作有幾方面，首先是整理野外調查資料。其中關 
於㖥的整理有兩个問題要注意，一是圖的格式，圖中要用統一的地曆代号、顏色和緰国 符号, 㘣侧諮明书要按規定去作。一是界綫的確定, 第四紀堆積物往往有过渡式混合性

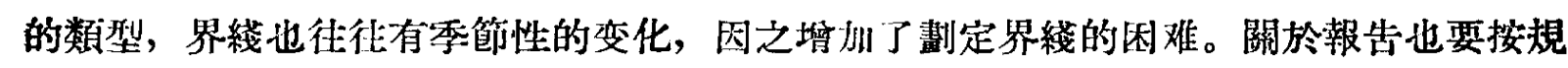

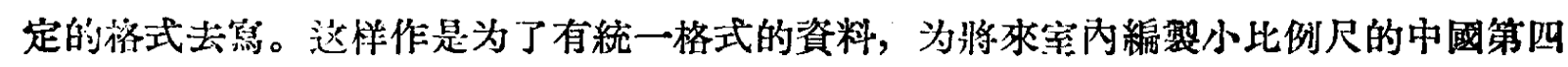
紀地檪圖打下基柘。

其次是已有資料的整理。这是一件繁重的工作。因为在过去我倗简積累了一些宝贵 的第四紀地翼（包括地貌）資料，要想將这些資料加以整理，非有水平較高的同志來領 導这个工作，显在一个長時期內繼續下去才有可能。我們建議先收集資料，編製卡片，

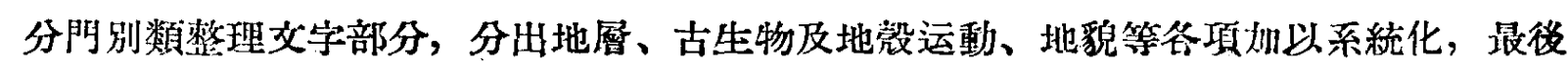
將得出的結果利用於編裴中國第四紀統一的地曆及地睤年表上。在整理已有資料工作中 最主要的还是在編製全國的第四紀地質圆上。这样的工作同样必須有人領䆃, 並先討論

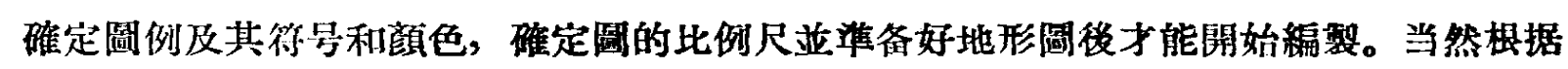
已有的資料，应先从中國东部編起。

在已有的資料中關於黃土的材料还是比較多的，因之，对黃土材料的整理就成为主 要任务之一。这个工作如在“所謂原生黄土全是風成的”覌點上去進行那当然是不可能 的。我們应当以实事求是的精神，科学的方法，並配合野外調查工作，先从黃士的性質、 䊅棈、分作与動力地質作用的關係以及地貌的表現等一系列的問题作起，然後根据成因 來分類分區，並編製黃士區的第四紀堆積圖及地貌圖，这样才有可能在農業廷没、工程 建設和齐避建設上加以充分利闸。

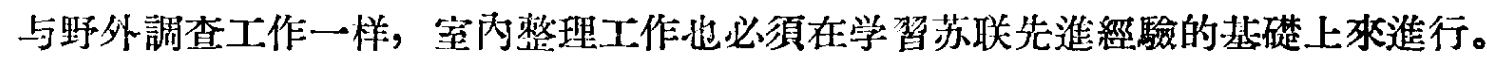

第三、我們从上面看來，中國第四紀地質工作的內容是非常多的，中國第四紀地罂 的資料是國家建設中非常需要的, 而且我們的人力少、矨識少、經驗少，这些工作都要 从头開始, 那碓如果沒有一个坚强的机構來統一領導和組織这个工作，是不可能有一个 好的開始的; 将是力量分散, 成果零星而無重點, 想達到最低的客覌要求地是不可能的。

在苏联，第四紀地翼的工作所以能有各方面的輝煌成就，不僅足人力多，科学水本

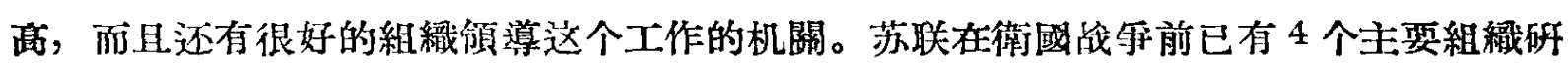
究筑四紀地睤的机關，那是：(1) 苏联地質事業委員会及其地方地質局;（2）國际第四

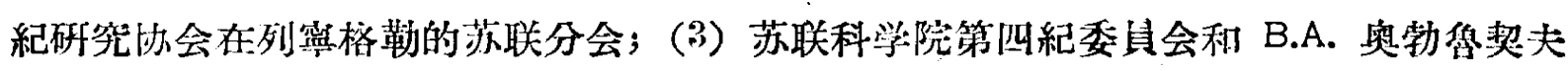
及 $\Gamma . \Phi$. 米尔琴克領導的第四紀部門; (4) 苏联科学院地理研究所、土壤研究所及烏克 蘭方州盟共和國科学院的第四紀部門（主要在地貌学方面）。除此而外，在一些大学裹地組 織了第四紀地質的調查和研究。

园之，我們希望首先在中國科学院和中央地罂部成立第四紀委員会和第四紀部門， 來組織領㰯全國的第阿紀地質工作，褧定部劃，定期完成，将研究的成柴应用在各項建 設上，來迎接沮國偉大汧会主义建没的演潮。 